Family Medicine and Community Health

\title{
COVID-19 disruption to family medicine residency curriculum: results from a 2020 US programme directors survey
}

\author{
Julia Fashner (D) , ${ }^{1}$ Anthony Espinoza, ${ }^{1}$ Arch G Mainous $3 r d^{2}$
}

To cite: Fashner J, Espinoza A, Mainous 3rd AG. COVID-19 disruption to family medicine residency curriculum: results from a 2020 US programme directors survey. Fam Med Com Health 2021;9:e001144. doi:10.1136/fmch-2021-001144

- Additional supplemental material is published online only. To view, please visit the journal online (http://dx.doi.org/10. 1136/fmch-2021-001144).

Data from the South Atlantic region was presented at the Florida Academy of Family Physicians Spring Meeting April 2021.

\section{Check for updates}

(c) Author(s) (or their employer(s)) 2022. Re-use permitted under CC BY-NC. No commercial re-use. See rights and permissions. Published by BMJ.

${ }^{1}$ Family Medicine Residency, Ocala Regional Medical Center Ocala, Florida, USA

${ }^{2}$ Health Services Research, Management and Policy; Department of Community Health and Family Medicine, University of Florida, Gainesville, Florida, USA

\section{Correspondence to} Dr Julia Fashner; julia.fashner.md@adventhealth. com

\section{ABSTRACT}

Objective This research project examined the effects of the COVID-19 pandemic on the required curriculum in graduate medical education for family medicine residencies.

Design Our questions were part of a larger omnibus survey conducted by the Council of Academic Family Medicine Educational Research Alliance. Data were collected from 23 September to 16 October 2020.

Setting This study was set in the USA.

Participants Emails were sent to 664 family medicine programme directors in the USA. Of the 312 surveys returned, 35 did not answer our questions and were excluded, a total of 277 responses (44\%) were analysed. Results The level of disruption varied by discipline and region. Geriatrics had the highest reported disruption (median=4 on a 5-point scale) and intensive care unit had the lowest (median=1 on a 5-point scale). There were no significant differences for disruption by type of programme or community size.

Conclusion Programme directors reported moderate disruption in family medicine resident education in geriatrics, gynaecology, surgery, musculoskeletal medicine, paediatrics and family medicine site during the pandemic. We are limited in generalisations about how region, type of programme, community size or number of residents influenced the level of disruption, as less than $50 \%$ of programme directors completed the survey.

\section{INTRODUCTION}

The COVID-19 pandemic has profoundly affected healthcare systems with shortages of personal protective equipment (PPE) and overloaded hospitals with severely ill patients. US medical students have had rotations cancelled in favour of virtual learning. ${ }^{1}$ Elective surgeries had been cancelled by many state governors. ${ }^{2}$ Nursing homes in the USA closed doors to outsiders due to the vulnerability of the elderly to the SARS-CoV-2 virus. ${ }^{3}$ The use of telehealth by physicians and patients has increased. ${ }^{4}$ Undoubtedly, this pandemic has affected family medicine resident training, but there is little evidence

\begin{abstract}
KEY POINTS
$\Rightarrow$ Question: Did the COVID-19 pandemic cause disruption to US family medicine residency required curriculum?

$\Rightarrow$ Finding: Overall, US programme directors rated geriatrics as the most disrupted and intensive care unit as the least disrupted curriculum. Disruptions in some curricular items were statistically different when compared by region of the USA. A majority of programme directors had low levels of concern regarding these disruptions, causing accreditation issues.

$\Rightarrow$ Meaning: The COVID-19 pandemic affected the US family medicine curriculum, certain regions more than others, but not to an extent that programme directors were concerned with accreditation.
\end{abstract}

related to the impact on graduate medical education (GME). ${ }^{56}$

US residency programmes are certified by the Accreditation Council for Graduate Medical Education (ACGME). This organisation sets requirements for institutions and sponsored residency programmes to ensure standards across the USA. Guidance on common programme requirements include the environment for learning skills, knowledge and attitudes during residency. ${ }^{7}$ There are also family medicine-specific requirements which detail oversight, evaluation, personnel and the educational programme. ${ }^{8}$ Family medicine is a 3-year training programme in the USA. The curriculum is varied among all specialties of medicine with required hours and/or patient visit counts for the following rotations: hospitalised adult patients, emergency department, geriatrics, inpatient and emergency department paediatrics, ambulatory paediatrics, newborn, surgery, musculoskeletal medicine (which must include sports medicine), gynaecology, obstetrics and health system management. These are usually done as block rotations of either 4 weeks or 
a month at a time. Each programme can design when in the 3 years of training any of these requirements is scheduled. ACGME also requires that family medicine residents have 40 weeks of continuity clinic at their assigned family medicine practice site each year. ${ }^{8}$

Surveys of US programme directors during the COVID-19 pandemic found high rates of changes made to residency programme curriculums in the specialties of oral surgery, paediatric gastroenterology, radiology, thoracic surgery urology and cardiology fellowship. These changes included redeployment of residents, ${ }^{9-11}$ suspension of surgical procedures, ${ }^{10-14}$ use of virtual didactics, ${ }^{11-14}$ decreased contact time with patients ${ }^{12-15}$ and concern about the negative impact on education, ${ }^{10-12} 15$ such as meeting case numbers. This research project will investigate the effects of the COVID-19 pandemic on education in family medicine residencies; specifically, the ACGME curriculum requirements for family medicine.

\section{METHODS}

Our questions were part of a larger omnibus survey conducted by the Council of Academic Family Medicine (CAFM) Educational Research Alliance (CERA). The CAFM, as an administrative committee, is made up of the leadership of four family medicine organisations: the Association of Departments of Family Medicine, the Association of Family Medicine Residency Directors (AFMRD), the North American Primary Care Research Group and the Society of Teachers of Family Medicine. ${ }^{16}$ CERA guides the specialty by providing leadership and vision in the arena of medical education research. CERA creates a way to complete medical education research, facilitates collaboration between researchers and provides mentoring to those whose projects are accepted. ${ }^{16}$ The CERA steering committee evaluated questions for consistency with the overall subproject aim, readability and existing evidence of reliability and validity. Pretesting was done on family medicine educators who were not part of the target population. Questions were modified following pretesting for flow, timing and readability.

The sampling frame for the survey was all ACGMEaccredited US family medicine residency programme directors as identified by the AFMRD. Email invitations to participate were delivered with the survey using the online program SurveyMonkey. Two follow-up emails to encourage non-respondents to participate were sent weekly after the initial email invitation and a third reminder was sent 2 days before the survey closed. There were 693 programme directors at the time of the survey, 1 had no email address indicated (692), 28 had previously opted out of SurveyMonkey surveys or their emails were undeliverable. Therefore, the survey was emailed to 664 individuals. The survey contained a qualifying question to remove programmes that had not had three resident classes. Forty programme directors indicated that they did not meet criteria; these responses were removed from the sample, reducing the sample size to 624 and respondents to 312.

Our questions (online supplemental appendix A) for each required curriculum item in family medicine used a 1-5 scale with the following anchors: $1=$ no disruption, $2=$ mild disruption, $3=$ moderate disruption, $4=$ severe disruption and 5 =suspended. The question regarding programme director being concern that COVID-19 would affect accreditation was on a 1-10 scale: $1=$ no concern, $3=$ little concern, $5=$ some concern, $7=$ moderate concern and $10=$ extraordinary concern.

The data collected on our questions were skewed; therefore, non-parametric tests were used. We provide descriptive assessment for the disruptions in curriculum as reported by programme directors. We used Kruskal-Wallis (KW) test to analyse if the ranks given to disruptions in a rotation were different among the demographic variables (region, type of programme, number of residents and community size). We provided descriptive analysis for programme directors being concern with accreditation and used KW test to analyse if there are differences between demographic variables for this variable. We used STATA V.14.2 (College Station, Texas, USA) for all analyses.

\section{RESULTS}

Of the 312 surveys returned, 35 responses were removed because none of our questions were answered. For one respondent who did not answer community size and number of residents, the missing value was imputed with the most common answer for that demographic item. Therefore, a total of 277 surveys were analysed. Demographics of the programme directors who responded are given in table 1 . Because this was an anonymous survey, we are unable to report any of the demographics for the programme directors who did not respond.

The curriculum with the highest disruption was geriatrics (median=4) and the lowest disruption was intensive care unit (ICU) (median=1) (table 2). There was a statistically significant difference in the reported disruption to family medicine residency curricula $(\mathrm{p}<0.001$, median $=4$ ). In subanalyses, type of programme and community size had no significant differences for the reported COVID-19 disruption of curricula. Disruptions reported by programme directors based on region had significant differences for several, but not all, required curricula (table 3). For number of residents, there was a significant difference for curriculum disruption only for the geriatrics $(\mathrm{p}<0.05)$ and newborn $(\mathrm{p}<0.05)$.

Programme directors' concern for accreditation due to COVID-19 disruption had a median score of 4 (IQR 3-7). The majority did not have major concerns, as $66 \%$ had no concern to some concern for accreditation (1-5 on the scale) (figure 1). In fact, $44 \%$ had no to minimal concern (1-3 out of 10). A scale of 1-10 allows for better detection of variance in the responses, yet in subanalyses, there were not significant differences in concern based on type 
Table 1 Demographics of US family medicine programmes $(\mathrm{N}=277)$

\begin{tabular}{|c|c|c|}
\hline Demographic & Categories & n (\%) \\
\hline \multirow{5}{*}{$\begin{array}{l}\text { Type of } \\
\text { programme }\end{array}$} & University based & $44(15.9)$ \\
\hline & $\begin{array}{l}\text { Community based, } \\
\text { university affiliated }\end{array}$ & 165 (59.6) \\
\hline & $\begin{array}{l}\text { Community based, } \\
\text { non-affiliated }\end{array}$ & $60(21.7)$ \\
\hline & Military & $5(1.8)$ \\
\hline & Other & $3(1.1)$ \\
\hline \multirow[t]{9}{*}{ Region } & $\begin{array}{l}\text { New England } \\
\text { (New Hampshire, } \\
\text { Massachusetts, } \\
\text { Main, Vermont, } \\
\text { Rhode Island, } \\
\text { Connecticut) }\end{array}$ & $11(4.0)$ \\
\hline & $\begin{array}{l}\text { Middle Atlantic } \\
\text { (New York, } \\
\text { Pennsylvania, New } \\
\text { Jersey) }\end{array}$ & 45 (16.3) \\
\hline & $\begin{array}{l}\text { South Atlantic } \\
\text { (Puerto Rico, } \\
\text { Florida, Georgia, } \\
\text { South Carolina, } \\
\text { North Carolina, } \\
\text { Virginia, District of } \\
\text { Columbia, West } \\
\text { virginia, Deleware, } \\
\text { Maryland) }\end{array}$ & 44 (15.9) \\
\hline & $\begin{array}{l}\text { East South } \\
\text { Central (Kentucky, } \\
\text { Tennessee, } \\
\text { Mississippi, } \\
\text { Alabama) }\end{array}$ & $16(5.8)$ \\
\hline & $\begin{array}{l}\text { East North Central } \\
\text { (Wisconsin, } \\
\text { Michigan, Ohio, } \\
\text { Indiana, Illinois) }\end{array}$ & 48 (17.3) \\
\hline & $\begin{array}{l}\text { West South } \\
\text { Central (Oklahoma, } \\
\text { Arkansas, } \\
\text { Louisiana, Texas) }\end{array}$ & $24(8.7)$ \\
\hline & $\begin{array}{l}\text { West North Central } \\
\text { (North Dakota, } \\
\text { Minnesota, South } \\
\text { Dakota, lowa, } \\
\text { Nebraska, Kansas, } \\
\text { Missouri) }\end{array}$ & $28(10.1)$ \\
\hline & $\begin{array}{l}\text { Mountain (Montana, } \\
\text { Idaho, Wyoming, } \\
\text { Nevada, Utah, } \\
\text { Arizona, Colorado, } \\
\text { New Mexico) }\end{array}$ & $26(9.4)$ \\
\hline & $\begin{array}{l}\text { Pacific (Washington, } \\
\text { Oregon, California, } \\
\text { Alaska, Hawaii) }\end{array}$ & $35(12.6)$ \\
\hline
\end{tabular}

Continued
Table 1 Continued

\begin{tabular}{lll}
\hline Demographic & Categories & n (\%) \\
\hline Community size & Less than 30000 & $29(10.5)$ \\
\cline { 2 - 3 } & 30000 to 74999 & $49(17.7)$ \\
\cline { 2 - 3 } 75000 to 149000 & $55(19.9)$ \\
& 150000 to 499999 & $68(24.6)$ \\
\cline { 2 - 3 } $\begin{array}{l}\text { Number of } \\
\text { residents }\end{array}$ & Mo0 000 to 1 million & $35(12.6)$ \\
& $<19$ & $41(14.8)$ \\
& $19-31$ & $106(38.3)$ \\
& $>31$ & $43(15.5)$
\end{tabular}

of programme or community size, just as with our findings for curriculum disruption. There was a significant difference in programme director being concern when analysed by region (table 4 ). There was also a significant difference $(\mathrm{p}<0.05)$ in concern by number of residents ( $>31$ residents (median=5), 19-31 residents (median=3) and $<19$ residents $($ median $=4)$ ).

\section{DISCUSSION}

There is limited literature on how family medicine resident education was affected by the COVID-19 pandemic. Three themes emerge: decreased in-person clinical care, increased virtual didactics and disrupted rotations. One programme in Colorado noted many of their residents served as back-up providers for the hospital in case of a surge, so they did not have an assigned rotation. ${ }^{17}$ Clinic sessions and didactics were changed to virtual meetings, with residents charged to participate in more self-directed

Table 2 Programme directors' rank of disruption to curriculum due to COVID-19 (median and IQR) $(p<0.001$; $\mathrm{N}=277$ )

\begin{tabular}{lll}
\hline & Median & IQR \\
\hline Adult medicine & 2 & $1-3$ \\
\hline Emergency medicine & 2 & $1-3$ \\
\hline Family medicine practice site & 3 & $3-4$ \\
\hline Geriatrics & 4 & $3-5$ \\
\hline Gynaecology & 3 & $2-4$ \\
\hline ICU & 1 & $1-2$ \\
\hline Musculoskeletal & 3 & $2-4$ \\
\hline Newborn & 2 & $1-3$ \\
\hline Obstetrics & 2 & $1-3$ \\
\hline Paediatrics & 3 & $2-3$ \\
\hline Practice management & 2 & $1-3$ \\
\hline Surgery & 3 & $2-4$
\end{tabular}

$1=$ no disruption, $2=$ mild disruption, $3=$ moderate disruption, $4=$ severe disruption and $5=$ suspended. ICU, intensive care unit. 

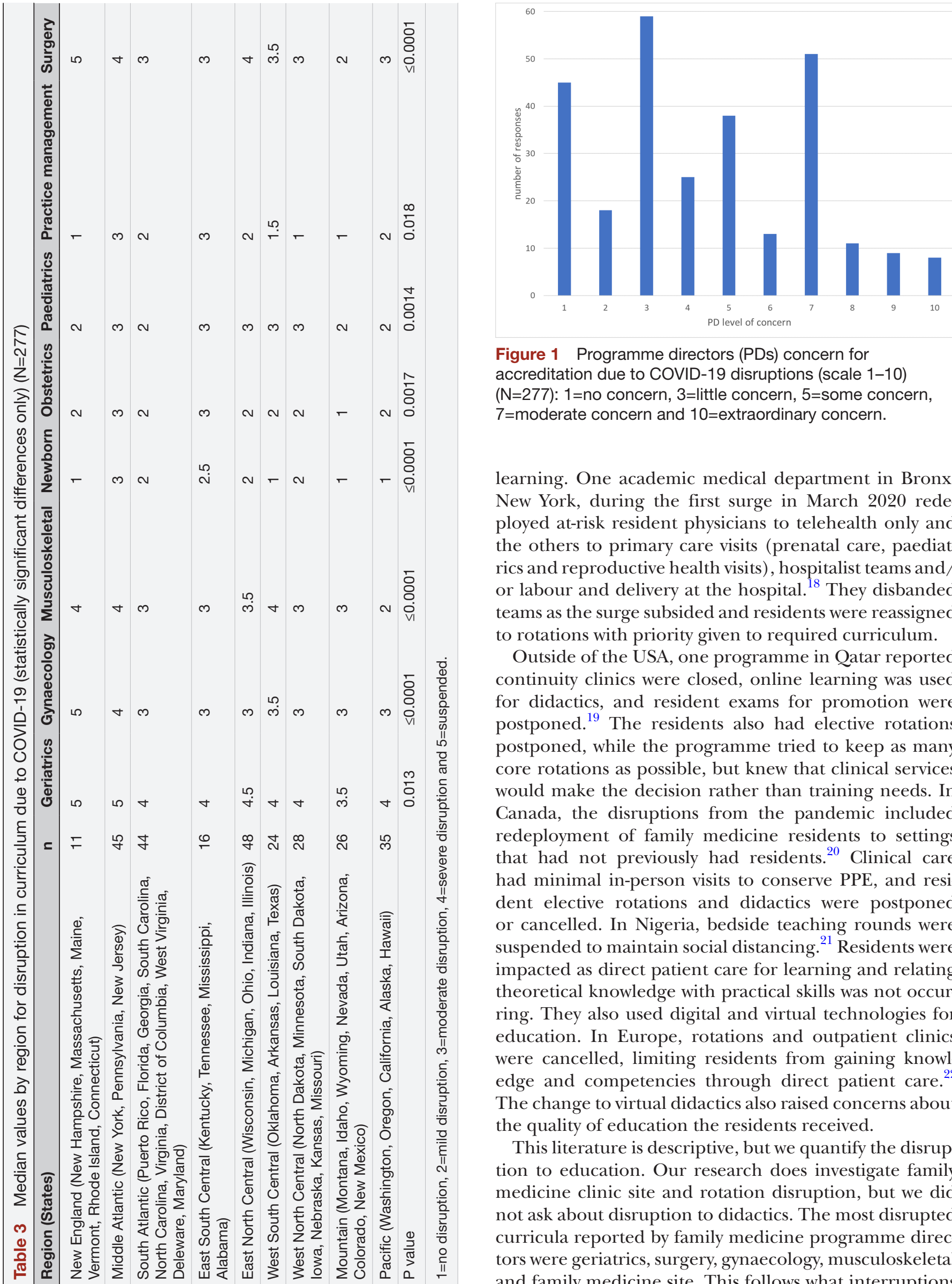

Figure 1 Programme directors (PDs) concern for accreditation due to COVID-19 disruptions (scale 1-10) $(\mathrm{N}=277)$ : $1=$ no concern, $3=$ little concern, $5=$ =some concern, $7=$ moderate concern and $10=$ extraordinary concern.

learning. One academic medical department in Bronx, New York, during the first surge in March 2020 redeployed at-risk resident physicians to telehealth only and the others to primary care visits (prenatal care, paediatrics and reproductive health visits), hospitalist teams and/ or labour and delivery at the hospital. ${ }^{18}$ They disbanded teams as the surge subsided and residents were reassigned to rotations with priority given to required curriculum.

Outside of the USA, one programme in Qatar reported continuity clinics were closed, online learning was used for didactics, and resident exams for promotion were postponed. ${ }^{19}$ The residents also had elective rotations postponed, while the programme tried to keep as many core rotations as possible, but knew that clinical services would make the decision rather than training needs. In Canada, the disruptions from the pandemic included redeployment of family medicine residents to settings that had not previously had residents. ${ }^{20}$ Clinical care had minimal in-person visits to conserve PPE, and resident elective rotations and didactics were postponed or cancelled. In Nigeria, bedside teaching rounds were suspended to maintain social distancing. ${ }^{21}$ Residents were impacted as direct patient care for learning and relating theoretical knowledge with practical skills was not occurring. They also used digital and virtual technologies for education. In Europe, rotations and outpatient clinics were cancelled, limiting residents from gaining knowledge and competencies through direct patient care. ${ }^{22}$ The change to virtual didactics also raised concerns about the quality of education the residents received.

This literature is descriptive, but we quantify the disruption to education. Our research does investigate family medicine clinic site and rotation disruption, but we did not ask about disruption to didactics. The most disrupted curricula reported by family medicine programme directors were geriatrics, surgery, gynaecology, musculoskeletal and family medicine site. This follows what interruptions 
Table 4 Programme directors concern for accreditation (scale 1-10) due to COVID-19 disruption by region ( $p=0.008 ; N=277$ )

\begin{tabular}{|c|c|c|c|}
\hline Region & $\mathbf{n}$ & Median & IQR \\
\hline $\begin{array}{l}\text { New England (New Hampshire, Massachusetts, Maine, Vermont, Rhode } \\
\text { Island, Connecticut) }\end{array}$ & 11 & 3 & $2-3$ \\
\hline Middle Atlantic (New York, Pennsylvania, New Jersey) & 45 & 6 & $4-7$ \\
\hline $\begin{array}{l}\text { South Atlantic (Puerto Rico, Florida, Georgia, South Carolina, North } \\
\text { Carolina, Virginia, District of Columbia, West Virginia, Deleware, Maryland) }\end{array}$ & 44 & 3 & $1-7$ \\
\hline East South Central (Kentucky, Tennessee, Mississippi, Alabama) & 16 & 4 & $3-7$ \\
\hline East North Central (Wisconsin, Michigan, Ohio, Indiana, Illinois) & 48 & 5 & $3-7$ \\
\hline West South Central (Oklahoma, Arkansas, Louisiana, Texas) & 24 & 3.5 & $3-5$ \\
\hline $\begin{array}{l}\text { West North Central (North Dakota, Minnesota, South Dakota, lowa, } \\
\text { Kansas, Missouri) }\end{array}$ & 28 & 3 & $1.5-7$ \\
\hline $\begin{array}{l}\text { Mountain (Montana, Idaho, Wyoming, Nevada, Utah, Arizona, Colorado, } \\
\text { New Mexico) }\end{array}$ & 26 & 3 & $1-5$ \\
\hline Pacific (Washington, Oregon, California, Alaska, Hawaii) & 35 & 5 & $3-7$ \\
\hline
\end{tabular}

occurred in the US healthcare system during COVID-19, namely, senior care facilities closing to outsiders, surgeries being cancelled and outpatient visits decreasing due to stay at home orders. We found the least disturbed family medicine curricula reported were obstetrics, newborn, practice management and surprisingly adult medicine, ICU and emergency medicine. If family medicine residents were called on to take care of severely ill patients during COVID-19 in the hospital, their rotation may have been changed to adult medicine, emergency medicine or ICU. That additional experience may have a positive connotation for the programme director, and therefore, make the disruption seem less severe. We are unable to measure that as our scale did not have positive or negative descriptors for the type of disruption that occurred.

With a majority of US family medicine programme directors expressing limited concern about accreditation, we should be reassured those programmes were able to adapt during the pandemic. ACGME had made clear that four core functions of programmes should remain in place during the COVID-19 pandemic: (1) abide by work hour requirements; (2) have adequate resources and training for residents, fellows, faculty caring for patients especially patients with or potentially with COVID-19 infection; (3) provide adequate supervision; and (4) fellows should function in their core specialty. ${ }^{23}$ Once ACGME site visits resume, family medicine educators (and probably other specialties) will want to know if accreditations and/or citations did occur more or less often after the pandemic. This would be a question to answer with future research. Other qualitative research could ask family medicine programme directors about work hour violations which occurred during the pandemic, restriction of PPE to residents and how much resident supervision was done in-person or virtually to address if these guidelines were followed. Programme directors and administrators will also want to know if graduates met the required number of clinic visits (1650), and if that target is not met will this be a citation?
There are several limitations to our study. The response rate was only $50 \%$, therefore, the findings may not represent all US family medicine GME. Each programme has its own curricular design for the required rotations and we are unable to account for this in our study. The timing of the CERA survey is also a constraint to the generalisability of our study to the entire pandemic. This research is a snapshot in the programme directors' experience up to the survey date, but case counts worsened with a winter surge in the USA. A follow-up survey to programme directors could evaluate if programmes still had education disruptions as the pandemic continues. We also specifically asked for programme directors to assess the disruption at the height of the pandemic. It is possible that adaptations had already occurred in the curriculum by the fall of 2020 and they reported how their programmes were doing at the time of the survey. This would make our results falsely lowered.

Understanding the disruptions and perceived consequences of this pandemic may aid in future planning for long-term disturbances in family medicine residency education. More manuscripts will likely be written about how medical educators adjusted their programmes due to the COVID-19 pandemic. It will be interesting to see how many of these changes continue in family medicine GME. Objective outcomes of the affected residents should be considered. The in-training exam scores could be studied to see if the pandemic had effects on subject area or overall scores. Future projects could compare board pass rates of family medicine graduates during this pandemic and those of previous years. Programme directors will likely do this for their programme, but as our findings point out, there will likely be regional variations.

\section{CONCLUSION}

There was significant variation in reported disruptions due to the COVID-19 pandemic for the required ACGME curriculum in US family medicine programmes. The 
most disrupted curricula (geriatrics, surgery and family medicine practice site) reflect some of the same disruptions that occurred in healthcare systems in the USA due to the pandemic. A majority of programme directors were confident that the pandemic would not create accreditation issues. The regional differences in the disruption and concern for accreditation were similar to the region where the initial COVID-19 surge occurred. ${ }^{24}$ These disruptions in family medicine curriculum are important to programme faculty and administrators, but with $<50 \%$ response rate, generalisability of our report may be limited.

Acknowledgements This research was supported (in whole or in part) by HCA Healthcare and/or an HCA Healthcare affiliated entity. The views expressed in this publication represent those of the author(s) and do not necessarily represent the official views of HCA Healthcare or any of its affiliated entities.

Contributors AE: Concept, survey questions, writing. JF: Concept, survey questions, writing, editing, statistical analysis, corresponding author. AGM: Mentor from CERA, editing.

Funding The authors have not declared a specific grant for this research from any funding agency in the public, commercial or not-for-profit sectors.

Competing interests None declared.

Patient consent for publication Not required.

Ethics approval The project was approved by the American Academy of Family Physicians Institutional Review Board in September 2020. Data were collected from 23 September 23 to 16 October 2020.

Provenance and peer review Not commissioned; externally peer reviewed.

Data availability statement Data may be obtained from a third party and are not publicly available. The Society of Teachers of Family Medicine make the data available to members 90 days after the release of the data to primary investigators.

Supplemental material This content has been supplied by the author(s). It has not been vetted by BMJ Publishing Group Limited (BMJ) and may not have been peer-reviewed. Any opinions or recommendations discussed are solely those of the author(s) and are not endorsed by BMJ. BMJ disclaims all liability and responsibility arising from any reliance placed on the content. Where the content includes any translated material, BMJ does not warrant the accuracy and reliability of the translations (including but not limited to local regulations, clinical guidelines, terminology, drug names and drug dosages), and is not responsible for any error and/or omissions arising from translation and adaptation or otherwise.

Open access This is an open access article distributed in accordance with the Creative Commons Attribution Non Commercial (CC BY-NC 4.0) license, which permits others to distribute, remix, adapt, build upon this work non-commercially, and license their derivative works on different terms, provided the original work is properly cited, appropriate credit is given, any changes made indicated, and the use is non-commercial. See: http://creativecommons.org/licenses/by-nc/4.0/.

\section{ORCID iD}

Julia Fashner http://orcid.org/0000-0002-6472-0029

\section{REFERENCES}

1 Murphy B. Online learning during COVID-19: tips to help Med students succeed, 2020. Available: https://www.ama-assn.org/ residents-students/medical-school-life/online-learning-during-covid19-tips-help-med-students [Accessed 15 Jan 2021].

2 Ambulatory Surgery Center Association. State guidance on elective surgeries, 2020. Available: https://www.ascassociation.org/asca/ resourcecenter/latestnewsresourcecenter/covid-19/covid-19-state [Accessed 15 Jan 2021].

3 Centers for Disease Control. Responding to coronavirus (COVID-19) in nursing homes. considerations for the public health response to COVID-19 in nursing homes, 2020. Available: https://www.cdc. gov/coronavirus/2019-ncov/hcp/nursing-homes-responding.htm [Accessed 15 Jan 2021].

4 Koonin LM, Hoots B, Tsang CA, et al. Trends in the use of telehealth during the emergence of the COVID-19 pandemic - United States, January-March 2020. MMWR Morb Mortal Wkly Rep 2020;69:1595-9.

5 Aggarwal G, Aggarwal S, Robles J, et al. Medical education focus in published articles related to COVID-19. Eur Rev Med Pharmacol Sci 2020;24:7905-7.

6 Tolu LB, Feyissa GT, Ezeh A, et al. Managing resident workforce and residency training during COVID-19 pandemic: Scoping review of adaptive approaches. Adv Med Educ Pract 2020;11:527-35.

7 Accreditation Council for Graduate Medical Education. Acgme common program requirements, 2020. Available: https:// www.acgme.org/Portals/O/PFAssets/ProgramRequirements/ CPRResidency2021.pdf [Accessed 21 Apr 2020].

8 Accreditation Council for Graduate Medical Education. Acgme program requirements for graduate medical education in family medicine, 2020. Available: https://www.acgme.org/Portals/0/ PFAssets/ProgramRequirements/120_FamilyMedicine_2021.pdf? ver=2021-06-22-162614-143 [Accessed 23 Jul 2020].

9 Breazzano MP, Shen J, Abdelhakim AH. New York City residency program directors COVID-19 Research Group. New York City COVID-19 resident physician exposure during exponential phase of pandemic. J Clin Invest 2020;130:4726-33.

10 Gupta T, Nazif TM, Vahl TP, et al. Impact of the COVID-19 pandemic on interventional cardiology fellowship training in the new York metropolitan area: a perspective from the United States EpiCenter. Catheter Cardiovasc Interv 2021;97:201-5.

11 Robbins JB, England E, Patel MD, et al. COVID-19 impact on well-being and education in radiology residencies: a survey of the association of program directors in radiology. Acad Radiol 2020;27:1162-72.

12 Coyan GN, Aranda-Michel E, Kilic A, et al. The impact of COVID-19 on thoracic surgery residency programs in the US: a program director survey. J Card Surg 2020;35:3443-8.

13 Brar B, Bayoumy M, Salama A, et al. A survey assessing the early effects of COVID-19 pandemic on oral and maxillofacial surgery training programs. Oral Surg Oral Med Oral Pathol Oral Radiol 2021;131:27-42.

14 Mallon D, Pohl JF, Phatak UP. NASPGHAN training Committee COVID-19 survey Working Group. impact of COVID-19 on pediatric gastroenterology fellow training in North America. J Pediatr Gastroenterol Nutr 2020;71:6-11.

15 Rosen GH, Murray KS, Greene KL, et al. Effect of COVID-19 on urology residency training: a nationwide survey of program directors by the Society of academic Urologists. J Urol 2020;204:1039-45.

16 Seehusen DA, Mainous AG, Chessman AW. Creating a centralized infrastructure to facilitate medical education research. Ann Fam Med 2018;16:257-60.

17 Devitt J, Malam N, Montgomery L. A family medicine residency program's response to an impending COVID-19 surge. J Am Board Fam Med 2021;34:S217-21.

18 Flattau A, Cristallo J, Duggan M, et al. Clinical redeployment of an academic family medicine department in an early, severe COVID-19 pandemic in the Bronx, NY. J Am Board Fam Med 2021;34:466-73.

19 Nasrallah MS, Tawfik HA, Aseel MT. Medicine residency training program during COVID-19: Qatari experience. Pan Afr Med J 2020;35:126

20 Wooltorton E, Seale E, Lewis D, et al. Rapid, collaborative generation and review of COVID-19 pandemic-specific competencies for family medicine residency training. Can Med Educ J 2020;11:e50-5.

21 Oseni TIA, Fatusin BB, Salam TO, et al. Effect of Covid-19 on family medicine training and education in Nigeria. Educ Prim Care 2021;18:1-2.

22 Windak A, Frese T, Hummers E, et al. Academic general practice/ family medicine in times of COVID-19 - perspective of WONCA Europe. Eur J Gen Pract 2020;26:182-8.

23 ACGME Response to Coronavirus (COVID-19), 2020. Available: https://www.acgme.org/Newsroom/Newsroom-Details/ArticlelD/ 10111/ACGME-Response-to-the-Coronavirus-COVID-19 [Accessed 1 Apr 2020].

24 Bajema KL, Wiegand RE, Cuffe K, et al. Estimated SARS-CoV-2 seroprevalence in the US as of September 2020. JAMA Intern Med 2021;181:450-60. 